\title{
Molecular detection of Rickettsia genus in chigger mites (Trombidiformes: Trombiculidae) collected on small mammals in southeastern brazilian
}

\author{
Detecção molecular do gênero Rickettsia em ácaros trombiculídeos (Trombidiformes: Trombiculidae) \\ coletados em pequenos mamíferos do sudeste brasileiro \\ Fernando de Castro Jacinaviciuss ${ }^{1,2}$ (D); Ricardo Bassini-Silva² (D); Sebastián Muñoz-Leal² (D); Cal Welbourn² (D); \\ Ronald Ochoa $^{4}$ (D); Marcelo Bahia Labruna ${ }^{2}$ (D); Darci Moraes Barros-Battesti ${ }^{2,5 *}$ (D)

\begin{abstract}
${ }^{1}$ Laboratório Especial de Coleçóes Zoológicas, Instituto Butantan, São Paulo, SP, Brasil
${ }^{2}$ Departamento de Medicina Veterinária Preventiva e Saúde Animal, Faculdade de Medicina Veterinária e Zootecnia - FMVZ, Universidade de São Paulo - USP, São Paulo, SP, Brasil

${ }^{3}$ Florida State Collection of Arthropods, Florida Department of Agriculture and Consumer Services, Gainesville, FL, USA

${ }^{4}$ Systematic Entomology Laboratory, United States Department of Agriculture, Agricultural Research Service, Beltsville, MD, USA

${ }^{5}$ Departamento de Patologia Veterinária, Faculdade de Ciências Agrárias e Veterinárias - FCAV, Universidade Estadual Paulista "Júlio de Mesquita Filho" - UNESP, Jaboticabal, SP, Brasil
\end{abstract}

Received April 23, 2019

Accepted August 08, 2019

\begin{abstract}
Chiggers are ectoparasites of vertebrates and may cause trombiculiasis or transmit pathogens to their hosts. Specimens collected from rodents and marsupials were morphologically identified as Herpetacarus hertigi, Eutrombicula tinami, Kymocta sp., Quadraseta brasiliensis, Quadraseta falconensis, Quadraseta flochi, Quadraseta mackenziei, Quadraseta pazca, Quadraseta trapezoides, Quadraseta sp., Serratacarus sp., and Trombewingia bakeri. These mites were submitted individually to molecular analyses for the detection of bacteria of the genus Coxiella, Hepatozoon and Rickettsia. Samples were positive to Rickettsia only. Obtained sequences for the $g l t A(350 \mathrm{pb})$ and $\operatorname{mop} A$ (488 pb) genes were identical to "Candidatus Rickettsia colombianensi", a species previously detected in ticks. In addition, molecular identification of mites based on 18S rDNA sequences are provided for H. hertigi, Kymocta sp., Q. brasiliensis, Q. pazca, Q. trapezoides, Quadraseta sp., and T. bakeri for the first time. This is the first report of the detection of a Rickettsia sp. in chigger mites collected on rodents in Brazil.
\end{abstract}

Keywords: Chiggers, "Candidatus Rickettsia colombianensi", ectoparasites, Rodentia, Didelphimorphia, Brazil.

\section{Resumo}

Os trombiculídeos são ectoparasitas de vertebrados e podem causar trombiculíase ou transmitir patógenos ao hospedeiro. Exemplares coletados em roedores e marsupiais foram identificados morfologicamente como Herpetacarus hertigi, Eutrombicula tinami, Kymocta sp., Quadraseta brasiliensis, Quadraseta falconensis, Quadraseta flochi, Quadraseta mackenziei, Quadraseta pazca, Quadraseta trapezoides, Quadraseta sp., Serratacarus sp. e Trombewingia bakeri. Estes ácaros foram submetidos individualmente à análise molecular para detecção de bactérias dos gêneros Coxiella, Hepatozoon e Rickettsia. Amostras foram positivas somente para Rickettsia. Sequências obtidas para os genes gltA (350 pb) e ompA (488 pb) foram idênticas à "Candidatus Rickettsia colombianensi”, uma espécie anteriormente detectada em carrapatos. Além disso, foram fornecidas sequências de DNA 18S para identificação molecular de H. hertigi, Kymocta sp., Q. brasiliensis, Q. pazca, Q. trapezoides, Quadraseta sp. e T. bakeri. Este é o primeiro registro da detecção de Rickettsia em ácaros trombiculídeos coletados em roedores do Brasil.

Palavras-chave: Trombiculídeos, “Candidatus Rickettsia colombianensi”, ectoparasitas, Rodentia, Didelphimorphia, Brasil.

\footnotetext{
*Corresponding author: Darci Moraes Barros-Battesti. Departamento de Patologia Veterinária, Faculdade de Ciências Agrárias e Veterinárias, Universidade Estadual Paulista "Júlio de Mesquita Filho" - UNESP, Via de Acesso Professor Paulo Donato Castelane, s/n, Vila Industrial, CEP 14884-900, Jaboticabal, SP, Brasil. e-mail: barros.battesti@gmail.com
} 


\section{Introduction}

Larval stages of trombiculid mites (Trombidiformes: Trombiculidae), also known as chiggers, typically parasitize terrestrial vertebrates and during feeding they inject digestive enzymes into the skin of their hosts. If infected, chiggers may transmit pathogens and/or cause severe skin reactions to the host, a disease commonly known as trombiculiasis (SANTIBÁÑEZ et al., 2015). In the Asia-Pacific region, chiggers are known as tsutsugamushi ("tsutsuga" = disease, "mushi" = bug), and are recognized vectors of Orientia tsutsugamushi, the agent of an acute febrile disease in humans, commonly known as Scrub typhus (RAPMUND et al., 1969; TAKAHASHI et al., 2004; KELLY et al., 2009; PHASOMKUSOLSIL et al., 2009).

Pathogenic microorganisms other than $O$. tsutsugamushi also can be found in trombiculid mites. Frank (1977) detected the presence of the protozoan Hepatozoon erhardovae in chiggers of the species Hirsutiella zachvatkini (Schluger 1948) in Austria, and Coxiella burnetii, the causative agent of Q-fever, was detected once in African chiggers (DANIEL, 1961; KEPKA, 1965). Furthermore, Blanc et al. (1952) successfully infected Neotrombicula autumnalis (Shaw 1790) with C. burnetii under laboratory conditions, and Le Gac et al. (1953) reported a Q-fever case in a laboratory technician who was handling chiggers from an endemic area in Equatorial Africa. On the other hand, bacteria of genus Rickettsia were detected in chiggers from Ukraine (VYSOTSKAYA \& SCHLUGER, 1953), Korea (CHOI et al., 2007) and China (HUANG et al., 2017). In particular, Rickettsia monacensis and Rickettsia helvetica were detected in mites from Slovakia (MIŤKOVÁ et al., 2015).

In Brazil, Fonseca (1932) emphasized the importance of mites as potential vectors in the epidemiological cycle of rickettsial diseases. Recently, Bassini-Silva et al. (2018a) detected a Rickettsia felis-like agent in the trombiculid Blankaartia sinnamaryi (Floch
\& Fauran, 1956) parasitizing birds, which corresponded to the first report of a rickettsial agent in Brazilian mites.

Here, we are contributing with the knowledge on molecular studies of chiggers parasitizing small mammals. In addition, we report the molecular detection of a Rickettsia sp. in three species of chiggers collected from three hosts.

\section{Materials and Methods}

\section{Molecular analyses}

Chiggers collected in São Paulo state, preserved in ethyl alcohol PA $100 \%$, stored in a $-80^{\circ} \mathrm{C}$ freezer, housed in the Acari Collection of the Instituto Butantan (IBSP) of São Paulo City, Brazil, were individually submitted to DNA extraction using the Guanidine Isothocianate (GT) lysis protocol following Chomczynski (1993). Each mite was placed into a plastic microtube and punctured in the idiosomal region with a sterile needle $(1.20 * 40-18 \mathrm{G})$. After DNA extraction, exoskeletons of the specimens were recovered and slide-mounted using Hoyer's medium in order to perform morphological identifications according to Walter \& Krantz (2009).

Conventional PCRs targeting a partial fragment of the mite $18 \mathrm{~S}$ ribosomal gene and a section of the mite mitochondrial cytochrome oxidase I (COI) gene were initially performed using thermal conditions and employed primers listed in Table 1. All reactions included a positive (DNA extracted from $B$. sinnamaryi) and a negative (DNA-free ultrapure water) control. As $18 \mathrm{~S}$ rRNA and COI gene-PCRs were used as endogenous controls, negative samples were excluded from further analyses.

Positive samples were then screened for agents in the genera Coxiella, Hepatozoon and Rickettsia through conventional and heminested PCR protocols. All the reactions included a negative

Table 1. Oligonucleotide primers used for the amplification of the genes $18 \mathrm{~S}$ rRNA and COI (endogenous controls), glt $A$ and $o m p A$ (Rickettsia), 16S rRNA (Coxiella) and 18S rRNA (Hepatozoon).

\begin{tabular}{|c|c|c|c|c|}
\hline Organisms & Gene & Sequence 5'-3' & Size (pb) & Reference \\
\hline Rickettsia spp. & glt $A$ & $\begin{array}{l}\text { CS-78 (GCAAGTATCGGTGAGGATGTAAT) } \\
\text { CS-323 (GCTTCCTTAAAATTCAATAAATCAGGAT) }\end{array}$ & 401 & Labruna et al. (2004) \\
\hline $\begin{array}{l}\text { Rickettsia spp. } \\
\quad(\mathrm{SPF})\end{array}$ & $\begin{array}{c}o m p A \\
\text { (1st round) }\end{array}$ & $\begin{array}{l}\text { Rr190.70 (ATGGCGAATATTTCTCCAAAA) } \\
\text { Rr190.701R2 (GTTCCGTTAATGGCAGCATCT) }\end{array}$ & 632 & $\begin{array}{l}\text { Regnery et al. (1991) and } \\
\quad \text { Roux et al. (1996) }\end{array}$ \\
\hline $\begin{array}{l}\text { Rickettsia spp. } \\
\quad(\mathrm{SPF})\end{array}$ & $\begin{array}{l}\quad \text { ompA } \\
\text { (hemi-nested) }\end{array}$ & $\begin{array}{l}\text { Rr190.70 (ATGGCGAATATTTCTCCAAAA) } \\
\text { Rr190.602 (AGTGCAGCATTCGCTCCCCCT) }\end{array}$ & 532 & Regnery et al. (1991) \\
\hline Coxiella spp. & $16 S$ & $\begin{array}{l}\text { 16SrRNA F (GGGGAAGAAAGTCTCAAGGGTAATATCCTT) } \\
\text { 16SrRNA R (TGCATCGAATTAAACCACATGCTCCACCGC) }\end{array}$ & 532 & Almeida et al. (2012) \\
\hline $\begin{array}{l}\text { Hepatozoon } \\
\text { spp. }\end{array}$ & $18 \mathrm{~S}$ & $\begin{array}{l}\text { HEP142-169-F (GCTTGAAACACTCTARTTTTCTCAAAG) } \\
\text { HEP743-718-R (ACAATAAAGTAAAAAACAYTTCAAAG) }\end{array}$ & 574 & Almeida et al. (2013) \\
\hline Mite & COI & $\begin{array}{l}\text { COI } 772 \text { (TGATTTTTTGGTCACCCAGAAG) } \\
\text { COI } 773 \text { (TACAGCTCCTATAGATAAAAC) }\end{array}$ & 408 & $\begin{array}{l}\text { Navajas et al. (1994) adapted } \\
\text { by Soller et al. (2001) }\end{array}$ \\
\hline Mite & $\mathrm{COI}$ & $\begin{array}{l}\text { bcdF01 CATTTTCHACTAAYCATAARGATATTGG } \\
\text { bcdR04 TATAAACYTCDGGATGNCCAAAAAA }\end{array}$ & $560-680$ & Dabert et al. $(2008,2010)$ \\
\hline Mite & COI & $\begin{array}{l}\text { LCO1490 GGTCAACAAATCATAAAGATATTGG } \\
\text { LCO2198 TAAACTTCAGGGTGACCAAAAAATCA }\end{array}$ & 710 & Folmer et al. (1994) \\
\hline Mite & $18 \mathrm{~S}$ & $\begin{array}{l}\text { 18S-1F (ATATTGGAGGGCAAGTCTGG) } \\
\text { 18S-1R (TGGCATCGTTTATGGTTAG) }\end{array}$ & 500 & Otto \& Wilson (2001) \\
\hline
\end{tabular}


control (DNA-free Milli-Q water) and an appropriate positive control, which consisted of DNA of Coxiella sp., extracted from infected Ornithodoros ticks; Hepatozoon canis, extracted from blood of an infected dog; and Rickettsia vini strain Breclav, extracted from an infected Vero cell culture. Reactions yielding amplicons of the expected size were treated with ExoSAP-IT (USB Corporation ${ }^{\circledR}$, $\mathrm{OH})$ following the manufacturer instructions $(3 \mu \mathrm{l}$ of ExoSAP with $7.5 \mu \mathrm{l}$ of the amplified DNA). Sanger sequencing of the amplicons was performed at the "Centro de pesquisa sobre Genoma Humano e Células Tronco do Instituto de Biociências da USP”. Obtained sequences were assembled and trimmed with Geneious R9 (KEARSE et al., 2012), and then submitted to BLASTn analyses (NCBI, 2019) in order to infer closest similarities with other homologous sequences (ALTSCHUL et al., 1990).

\section{Morphological tools}

The slide-mounted voucher specimens were identified to the genus level using the key by Brennan \& Goff (1977), and to the species level based on the original descriptions cited in the Brazilian checklist of chiggers (JACINAVICIUS et al., 2018b). Additional comparisons were made with type series and other specimens deposited in the mite collection of the United State National Museum (USNM), currently housed at the Systematic Entomology Laboratory, Beltsville, Maryland, USA (BARC-USDA-ARS).

\section{Results}

The 317 chiggers examined at the IBSP were collected from nine cricetid rodents (Akodon montensis, Akodon sp., Delomys sublineatus, Euryoryzomys russatus, Hylaeamys megacephalus, Necromys lasiurus, Nectomys squamipes, Oligoryzomys sp. and Thaptomys nigrita), one echimyid rodent (Thrichomys fosteri), and four marsupials (Didelphis aurita, Gracilinanus agilis, Monodelphis americana, Monodelphis domestica and Thylamys macrurus). After DNA extraction, mites were slide mounted and morphologically identified generating the following vouchers: Herpetacarus hertigi (Brennan, 1970) (22), Eutrombicula tinami (Oudemans, 1910) (14), Kymocta sp. (7), Quadraseta brasiliensis Goff and Gettinger, 1989 (175), Quadraseta falconensis Goff and Brennan, 1977 (6), Quadraseta flochi (Brennan and Jones, 1960) (5), Quadraseta mackenziei (Yunker and Brennan, 1964) (4), Quadraseta pazca (Brennan and Jones, 1964) (54), Quadraseta trapezoides (Brennan and Jones, 1964) (11), Quadraseta sp. (9), Serratacarus sp. (1) and Trombewingia bakeri (Fonseca, 1955) (9).

A total of 20 samples yielded expected size amplicons for the mite $18 \mathrm{~S}$ rRNA gene. Obtained sequences corresponded to a unique haplotype for each of the following seven chigger species. The GenBank accession numbers are: one H. hertigi (MG817637), two Kymocta sp. (MG817642), four Q. brasiliensis (MG817643), two Q. pazca (MG817644), seven Q. trapezoides (MG817645), one Quadraseta sp. (KY934461), and three T. bakeri (MG817646). One amplified sample of $Q$. pazca did not generate a good quality sequence and was not deposited in GenBank. Attempts to amplify fragments of the COI gene from all samples were unsuccessful. After BLASTn analyses, consensus sequences of $H$. hertigi, Kymocta sp., Q. brasiliensis, Q. pazca, Q. trapezoides, Quadraseta sp., and T. bakeriwere $98.63 \%$ (431/437-pb), 99.51\% (408/410-pb), $99.50 \%$ (397/399-pb), 99.75\% (404/405-pb), 98.77\% (400/405-pb), $98.39 \%$ (428/435-pb), and 99.50\% (397/399-pb) identical with a homologous sequence of Eutrombicula splendens (Ewing, 1913) (KY922159).

All 20 samples positive for $18 \mathrm{~S}$ rDNA PCR assays were tested for Coxiella, Hepatozoon and Rickettsia. A total of 13 samples yielded rickettsial $g l t A$ amplicons, but only six were successfully sequenced. In addition, one sample also yielded rickettsial $o m p A$ amplicons. PCR targeting 16S rDNA gene of Coxiella sp. and $18 \mathrm{~S}$ rDNA gene of Hepatozoon sp. were negative. Sequences of Rickettsia were submitted to BLASTn analysis. Six identical gltA sequences were $100 \%$ (350/350 bp) identical to "Candidatus Rickettsia colombianensi” (MG970682). These sequences came from one larva of $H$. hertigi, three larvae of $Q$. trapezoides and two of T. bakeri. Besides that, one of the successfully-sequenced ompA samples was $100 \%$ (488/488 bp) identical to " $C a$. Rickettsia colombianensi" (MG970683) as well. Sequences of Rickettsia generated in the current study were deposited in GenBank under the accession numbers MG906649, MG906650, MG906652, MG906653, MG906654, MG906656.

Overall, one species of $H$. hertigi collected in Fontes do Ipiranga State Park (PEFI), São Paulo municipality, parasitizing an Oligoryzomys sp.; three specimens of Q. trapezoides from Morro Grande, Cotia municipality, collected on Nectomys squamipes; and two specimens of T. bakeri collected in Campos do Jordão municipality, on Akodon montensis, were positive for " $\mathrm{Ca}$. Rickettsia colombianensi”.

\section{Discussion}

The successful amplification rates for the mite $18 \mathrm{~S}$ rRNA gene upon individual chiggers, was $13.63 \%(3 / 22)$ for $H$. hertigi, $28.57 \%$ (2/7) for Kymocta sp., 2.28\% (4/175) for Q. brasiliensis, 5.55\% (3/54) for Q. pazca, 63.64\% (1/11) for Q. trapezoides, $11.11 \%$ (1/9) for Quadraseta sp., and 33.33\% (3/9) for T. bakeri. Amplification of this same locus was unsuccessful for E. tinami, Q. falconensis, Q. flochi, Q. mackenziei and Serratacarus sp. We were successful in amplifying only 7.26\% (20/317) of all individually tested species, while Bassini-Silva et al.(2018a) obtained a $72.5 \%$ (29/40) of success in amplifying the same gene for B. sinnamaryi. Park et al. (2015) successfully amplified the $18 \mathrm{~S}$ rRNA gene in 50\% (38/76) for Helenicula miyagawai (Sasa, Kumada and Miura, 1951) mites, and in $87.5 \%$ (7/8) for Leptotrombidium scutellare (Nagayo, Miyagawa, Mitamura, Tamiya and Tenjin, 1921).

Of the 73 chiggers species reported from Brazil, $18 \mathrm{~S}$ rDNA sequences were previously available for only three species: B. sinnamaryi (MG783391) (BASSINI-SILVA et al., 2018a), Eutrombicula daemoni Bassini-Silva and Jacinavicius, 2018 (MG707783, MG70778) (BASSINI-SILVA et al., 2018b), and Q. brasiliensis (MF113413, MF113412, KY934462, KY934463, KY934464) (JACINAVICIUS et al., 2018a). In the present study, we provide new $18 \mathrm{~S}$ rDNA sequences for $H$. hertigi, Kymocta sp., Q. pazca, Q. trapezoides, and T. bakeri. According to Hillis \& Dixon (1991) and Cruickshank (2002), the 18S rRNA gene 
has a slow rate of evolution and it is suitable to infer family and subfamily level phylogenies. As the availability of sequences of this locus for chiggers from South America is still scarce, the creation of a South American chigger gene bank may afford the inclusion of these taxa in future phylogenetic studies dealing with the relationships between mites in higher groupings.

The mitochondrial COI gene has a faster rate of sequence divergence if compared with nuclear ribosomal genes (OTTO \& WILSON, 2001). Kampen et al. (2004), Moniuszko et al. (2015) and Kumlert et al. (2018) successfully amplified this gene for some chigger species of the genera Ascoschoengastia, Blankaartia, Hirsutella, Leptotrombidium, Neotrombicula, Schoengastia, Schoutedenichia, and Walchia, from Europe and Asia. Although in the current study we employed this same pairs of primers, none of our samples yielded amplicons, which is in the line with previous studies in Brazil (BASSINI-SILVA et al., 2018a; JACINAVICIUS et al., 2018a). We highlight then the need for testing new sets or designing new primers that will successfully amplify this gene for South American chiggers.

Rickettsial DNA identical to two "Ca. Rickettsia colombianensi" genes was detected in three chigger species for the first time, all from the state of São Paulo. "Ca. Rickettsia colombianensi" was originally characterized from the tick Amblyomma dissimile Koch, 1844 in Colombia (MIRANDA et al., 2012). In Brazil, this species of Rickettsia sp. was recently detected in $A$. dissimile from Amazon biome of Amapá state (LUZ et al., 2018), and the current finding extends its occurrence to further Acari representatives, in particular, to trombiculid mites in the Atlantic rainforest biome of the Sáo Paulo state. "Candidatus R. colombianensi” belongs to the spotted fever group of rickettsiae, and its isolation in Vero cells has demonstrated a marked cytopathic effect (MIRANDA et al., 2019). Although infection in cattle and iguanas has been suggested in Colombia (MIRANDA et al., 2012), the role of " $\mathrm{Ca}$. Rickettsia colombianensi" as a pathogenic agent is still obscure.

The single record of Rickettsia in chiggers from Brazil was documented by Bassini-Silva et al. (2018a), and correspond to a Rickettsia felis-like agent detected in B. sinnamaryi, collected on Tachyphonus coronatus (Aves: Passeriformes) from the state of Minas Gerais. However, Rickettsia spp. have been reported from various mites collected on birds and mammals (VYSOTSKAYA \& SCHLUGER, 1953; HASE et al., 1978; CHOI et al., 2007; TAKAHASHI et al., 2004; MIŤKOVÁ et al., 2015; HUANG et al. 2017; BASSINI-SILVA et al., 2018a), which suggest that our finding is not an isolated case. On the other hand, we had no success in detecting the presence of Coxiella sp. and Hepatozoon sp. in the analyzed chiggers.

This is the first report of Rickettsia detection in chiggers collected on rodents in Brazil. As studies on chiggers as possible vectors of Rickettsia are scarce in the Neotropical region, more prospections are needed to determine if these mites are, in fact, involved in the epidemiological cycles of rickettsial diseases.

\section{Acknowledgements}

To Gabrielle Ribeiro de Andrade and Maria Cristina Ferreira do Rosário for technical contributions (CNPq no. 377343/2015-3 and 377342/2015-7, respectively). To Debra D. Creel for the technical support. To Melissa K. Miller, entomologist, Public Health Command - Atlantic, Fort Meade, Maryland instead of entomologist U.S. Army Forces, for her valuable comments on this manuscript. This work was supported by the Conselho Nacional de Desenvolvimento Científico e Tecnológico (CNPq no. 454907/2014-1 and 440639/2015-8 to DMB-B, 377976/2014-8 to FCJ), Fundação de Amparo à Pesquisa do Estado de Sáo Paulo (FAPESP no. 2010/51875-9 to DMB-B and 2017/01416-7 to RB-S). Mention of trade names or commercial products in this publication is solely for the purpose of providing specific information and does not imply recommendation or endorsement by the USDA; USDA is an equal opportunity provider and employer. This study was financed in part by the Coordenação de Aperfeiçoamento de Pessoal de Nível Superior - Brasil (CAPES) - Finance Code 001.

\section{References}

Almeida AP, Marcili A, Leite RC, Nieri-Bastos FA, Domingues LN, Martins JR, et al. Coxiella symbiont in the tick Ornithodoros rostratus (Acari: argasidae). Ticks Tick Borne Dis 2012; 3(4): 203-206. http:// dx.doi.org/10.1016/j.ttbdis.2012.02.003. PMid:22480930.

Almeida AP, Souza TD, Marcili A, Labruna MB. Novel Ehrlichia and Hepatozoon agents infecting the crab-eating fox (Cerdocyon thous) in southeastern Brazil. J Med Entomol 2013; 50(3): 640-646. http://dx.doi. org/10.1603/ME12272. PMid:23802461.

Altschul SF, Gish W, Miller W, Myers EW, Lipman DJ. Basic local alignment search tool. J Mol Biol 1990; 215(3): 403-410. http://dx.doi. org/10.1016/S0022-2836(05)80360-2. PMid:2231712.

Bassini-Silva R, Jacinavicius FC, Maturano R, Muñoz-Leal S, Ochoa R, Bauchan G, et al. Blankaartia sinnamaryi (Trombidiformes: Trombiculidae) parasitizing birds in southeastern Brazil, with notes on Rickettsia detection. Rev Bras Parasitol Vet 2018a; 27(3): 354-362. http://dx.doi.org/10.1590/ s1984-296120180057. PMid:30184002.

Bassini-Silva R, Jacinavicius FC, Muñoz-Leal S, Maturano R, Welbourn WC, Ochoa R, et al. A new species of the genus Eutrombicula Ewing, 1938 (Trombidiformes: Trombiculidae) and new records for the species Eutrombicula batatas (Linnaeus, 1758) in Brazil. Acarologia 2018b; 58(4): 976-986. http://dx.doi.org/10.24349/acarologia/20184304.

Blanc G, Joyeux C, Bruneau J. Observations sur les larves de Trombicula autumnalis (SHAW) dans le centre de la France. Recherches sur leur role possible dans la transmission de la maladie de Derrick-Burnet (Q-Fever). Arch Inst Pasteur Maroc 1952; 4: 314-325.

Brennan JM, Goff ML. Keys to the genera of chiggers of the Western Hemisphere (Acarina: trombiculidae). J Parasitol 1977; 63(3): 554-566. http://dx.doi.org/10.2307/3280021. PMid:68115.

Choi YJ, Lee EM, Park JM, Lee KM, Han SH, Kim JK, et al. Molecular detection of various rickettsiae in mites (Acari: Trombiculidae) in southern Jeolla Province, Korea. Microbiol Immunol 2007; 51(3): 307-312. http:// dx.doi.org/10.1111/j.1348-0421.2007.tb03912.x. PMid:17380050.

Chomczynski P. A reagent for the single-step simultaneous isolation of RNA, DNA and proteins from cell and tissue samples. Biotechniques 1993; 15(3): 532-534, 536-537. PMid:7692896.

Cruickshank RH. Molecular markers for the phylogenetics of mites and ticks. Syst Appl Acarol 2002; 7(0): 3-14. http://dx.doi.org/10.11158/ saa.7.1.1. 
Dabert J, Ehrnsberger R, Dabert M. Glaucalges tytonis sp. n. (Analgoidea, Xolalgidae) from the barn owl Tyto alba (Strigiformes, Tytonidae): compiling morphology with DNA barcode data for taxon description in mites (Acari). Zootaxa 2008; 1719: 41-52.

Dabert M, Witalinski W, Kazmierski A, Olszanowski Z, Dabert J. Molecular phylogeny of acariform mites (Acari, Arachnida): strong conflict between phylogenetic signal and long-branch attraction artifacts. Mol Phylogenet Evol 2010; 56(1): 221-241. http://dx.doi.org/10.1016/j. ympev.2009.12.020. PMid:20060051.

Daniel M. The bionomics and developmental cycle of some chiggers (Acariformes, Trombiculidae) in the Slovak Carpathians. Cs Parasitol 1961; 8: 31-118.

Folmer O, Black M, Hoeh W, Lutz R, Vrijenhoek R. DNA primers for amplification of mitochondrial cytochrome $c$ oxidase subunit I from diverse metazoan invertebrates. Mol Mar Biol Biotechnol 1994; 3(5): 294-299. PMid:7881515.

Fonseca F. Notas de Acareologia I. Papel dos acarianos do gênero Trombicula na transmissão das Rickettsias pathogenicas e aplicação dessa hypothese à Rickettsia brasiliensis Montero, 1931. Mem Inst Butantan 1932; 3: 127-133.

Frank C. Ein Beitrag zur Biologie von Hepatozoon erhardovae Krampitz 1964 in Rötelmäusen aus der Südweststeiermark und des Neusiedlerseegebietes (Burgenland). Parasitol Res 1977; 53(3): 251-254. http://dx.doi. org/10.1007/BF00389940.

Hase T, Roberts LW, Hildebrandt PK, Cavanaugh DC. Stylostome formation by Leptotrombidium mites (Acari: trombiculidae). J Parasitol 1978; 64(4): 712-718. http://dx.doi.org/10.2307/3279967. PMid:98623.

Hillis DM, Dixon MT. Ribosomal DNA: molecular evolution and phylogenetic inference. QRev Biol 1991; 66(4): 411-453. http://dx.doi. org/10.1086/417338. PMid:1784710.

Huang Y, Zhao L, Zhang Z, Liu M, Xue Z, Ma D, et al. Detection of a novel Rickettsia from Leptotrombidium scutellare Mites (Acari: Trombiculidae) from shandong of China. J Med Entomol 2017; 54(3): 544-549. http:// dx.doi.org/10.1093/jme/tjw234. PMid:28399204.

Jacinavicius FC, Bassini-Silva R, Mendoza-Roldan JA, Muñoz-Leal $S$, Hingst-Zaher E, Ochoa R, et al. A contribution to the knowledge of Quadraseta brasiliensis Goff and Gettinger, 1989 (Trombidiformes: Trombiculidae), with description of the deutonymph instar. Acarologia 2018a; 58(2): 442-456. http://dx.doi.org/10.24349/acarologia/20184252.

Jacinavicius FC, Bassini-Silva R, Mendoza-Roldan JA, Pepato AR, Ochoa $\mathrm{R}$, Welbourn C, et al. A checklist of chiggers from Brazil, including new records (Acari: Trombidiformes: Trombiculidae and Leeuwenhoekiidae). ZooKeys 2018b; 743(1): 1-41. http://dx.doi.org/10.3897/zookeys.743.22675. PMid:29670435.

Kampen H, Scholer A, Metzen M, Oehme R, Hartelt K, Kimmig P, et al. Neotrombicula autumnalis (Acari, Trombiculidae) as a vector for Borrelia burgdorferi sensu lato? Exp Appl Acarol 2004; 33(1-2): 93-102. http:// dx.doi.org/10.1023/B:APPA.0000029975.92510.90. PMid:15285141.

Kearse M, Moir R, Wilson A, Stones-Havas S, Cheung M, Sturrock $S$, et al. Geneious basic: an integrated and extendable desktop software platform for the organization and analysis of sequence data. Bioinformatics 2012; 28(12): 1647-1649. http://dx.doi.org/10.1093/bioinformatics/ bts199. PMid:22543367.

Kelly DJ, Fuerst PA, Ching WM, Richards AL. Scrub typhus: the geographic distribution of phenotypic and genotypic variants of Orientia tsutsugamushi. Clin Infect Dis 2009; 48(Suppl.3): S203-S230. http:// dx.doi.org/10.1086/596576. PMid:19220144.
Kepka O. Merkblätter über angewandte Parasitenkunde und Schädlingsbekämpfung, Merkblatt Nr. 12: Die Herbstmilbe (Neotrombicula autumnalis). Angew Parasitol Beilage 1965; 6(4): 1-13.

Kumlert R, Chaisiri K, Anantatat T, Stekolnikov AA, Morand S, Prasartvit A, et al. Autofluorescence microscopy for paired-matched morphological and molecular identification of individual chigger mites (Acari: Trombiculidae), the vectors of scrub typhus. PLoS One 2018; 13(3): e0193163. http://dx.doi.org/10.1371/journal.pone.0193163. PMid:29494599.

Labruna MB, Whitworth T, Horta MC, Bouyer DH, McBride JW, Pinter A, et al. Rickettsia species infecting Amblyomma cooperi ticks from an area in the state of São Paulo, Brazil, where Brazilian spotted fever is endemic. J Clin Microbiol 2004; 42(1): 90-98. http://dx.doi.org/10.1128/ JCM.42.1.90-98.2004. PMid:14715737.

Le Gac P, Giroud P, Andre M, Roger F. Deux modes de contamination professionnelle par la fièvre Q. Bull Soc Pathol Exot 1953; 46: 659-662.

Luz HR, Silva-Santos E, Costa-Campos CE, Acosta I, Martins TF, Muñoz-Leal S, et al. Detection of Rickettsia spp. in ticks parasitizing toads (Rhinella marina) in the northern Brazilian Amazon. Exp Appl Acarol 2018; 75(3): 309-318. http://dx.doi.org/10.1007/s10493-0180270-y. PMid:29846852.

Miranda J, Mattar S, Puerta-González A, Muskus C, Oteo JA. Genome sequence of "Candidatus Rickettsia colombianensi", a novel tick-associated bacterium distributed in Colombia. Microbiol Resour Announc 2019; 8(14): e01433-18. https://dx.doi.org/10.1128\%2FMRA.01433-18.

Miranda J, Portillo A, Oteo JA, Mattar S. Rickettsia sp. Strain Colombianensi (Rickettsiales: Rickettsiaceae): a new proposed Rickettsia detected in Amblyomma dissimile (Acari: Ixodidae) from Iguanas and free-living larvae ticks from vegetation. JMed Entomol 2012; 49(4): 960-965. http:// dx.doi.org/10.1603/ME11195. PMid:22897060.

Mitková K, Berthová L, Kalúz S, Kazimírová M, Burdová L, Kocianová E. First detections of Rickettsia helvetica and R. monacensis in ectoparasitic mites (Laelapidae and Trombiculidae) infesting rodents in south-western Slovakia. Parasitol Res 2015; 114(7): 2465-2472. http://dx.doi.org/10.1007/ s00436-015-4443-x. PMid:25843569.

Moniuszko H, Zaleśny G, Mąkol J. Host-associated differences in morphometric traits of parasitic larvae Hirsutiella zachvatkini (Actinotrichida: trombiculidae). Exp Appl Acarol 2015; 67(1): 123-133. http://dx.doi. org/10.1007/s10493-015-9925-0. PMid:26002309.

National Center for Biotechnology Information - NCBI. Blastn [online]. 2019 [cited 2019 Mar 10]. Available from: www.ncbi.nlm.nih.gov/blast

Navajas M, Gutierrez J, Bonato O, Bolland HR, Mapangou-Divassa S. Intraspecific diversity of the cassava green mite Mononychellus progressivus (Acari: Tetranychidae) using comparisons of mitochondrial and nuclear ribosomal DNA sequences and cross-breeding. Exp Appl Acarol 1994; 18(6): 351-360. http://dx.doi.org/10.1007/BF00116316. PMid:7628252.

Otto JC, Wilson KJ. Assessment of the usefulness of ribosomal 18S and mitochondrial COI sequences in Prostigmata phylogeny. In: Proctor HC, Norton RA, Colloff MJ. Acarology: Proceedings of the 10th International Congress; 2011; Collingwood, Australia. Melbourne: CSIRO Publishing; 2001. p. 100-109.

Park SW, Ha NY, Ryu B, Bang JH, Song H, Kim Y, et al. Urbanization of scrub typhus disease in South Korea. PLoS Negl Trop Dis 2015; 9(5): e0003814. http://dx.doi.org/10.1371/journal.pntd.0003814. PMid:26000454. 
Phasomkusolsil S, Tanskul P, Ratanatham S, Watcharapichat P, Phulsuksombati D, Frances SP, et al. Transstadial and transovarial transmission of Orientia tsutsugamushi in Leptotrombidium imphalum and Leptotrombidium chiangraiensis (Acari: trombiculidae). J Med Entomol 2009; 46(6): 1442-1445. http://dx.doi.org/10.1603/033.046.0628. PMid:19960694.

Rapmund G, Upham RW Jr, Kundin WD, Manikumaran C, Chan TC. Transovarial development of scrub typhus rickettsiae in a colony of vector mites. Trans R Soc Trop Med Hyg 1969; 63(2): 251-258. http://dx.doi. org/10.1016/0035-9203(69)90155-2. PMid:4978468.

Regnery RL, Spruill CL, Plikaytis BD. Genotypic identification of rickettsiae and estimation of intraspecies sequence divergence for portions of two rickettsial genes. J Bacteriol 1991; 173(5): 1576-1589. http:// dx.doi.org/10.1128/jb.173.5.1576-1589.1991. PMid:1671856.

Roux V, Fournier PE, Raoult D. Differentiation of spotted fever group rickettsiae by sequencing and analysis of restriction fragment length polymorphism of PCR-amplified DNA of the gene encoding the protein rOmpA. J Clin Microbiol 1996; 34(9): 2058-2065. PMid:8862558.

Santibáñez PA, Palomar M, Portillo A, Santibáñez S, Oteo JA. The role of chiggers as human pathogens. In: Samie A. An overview of tropical diseases. London: Intech; 2015. p. 173-202. http://dx.doi. org/10.5772/61978.

Schluger EG. New red mites (Acari, Trombidiidae) of the fauna of the USSR. Entomol Obozr 1948; 30: 157-164.

Soller R, Wohltmann A, Witte H, Blohm D. Phylogenetic relationships within terrestrial mites (Acari: Prostigmata, Parasitengona) inferred from comparative DNA sequence analysis of the mitochondrial cytochrome oxidase subunit I gene. Mol Phylogenet Evol 2001; 18(1): 47-53. http:// dx.doi.org/10.1006/mpev.2000.0855. PMid:11161741.

Takahashi M, Misumi H, Urakami H, Nakajima S, Furui S, Yamamoto $S$, et al. Mite vectors (Acari: Trombiculidae) of scrub typhus in a new endemic area in northern Kyoto, Japan. J Med Entomol 2004; 41(1): 107-114. http://dx.doi.org/10.1603/0022-2585-41.1.107. PMid:14989353.

Vysotskaya SO, Schluger EG. Licinki krasnotelok-parazity gryzunov Leningradskoj oblasti. Parazitologicheskii Sbornik 1953; 15: 345-352.

Walter DE, Krantz GW. Collecting, rearing, and preparing specimens. In: Krantz GW, Walter DE. A manual of acarology. Lubbock: Texas Tech University Press; 2009. p. 83-96. 